This is an electronic reprint of the original article. This reprint may differ from the original in pagination and typographic detail.

Author(s): Pöyhönen, Sari; Tarnanen, Mirja

Title: Integration policies and adult second language learning in Finland

Year: $\quad 2015$

Version:

Please cite the original version:

Pöyhönen, S., \& Tarnanen, M. (2015). Integration policies and adult second language learning in Finland. In J. Simpson, \& A. Whiteside (Eds.), Adult Language Education and Migration : Challenging agendas in policy and practice (pp. 107-118). Routledge. https://doi.org/10.4324/9781315718361-8

All material supplied via JYX is protected by copyright and other intellectual property rights, and duplication or sale of all or part of any of the repository collections is not permitted, except that material may be duplicated by you for your research use or educational purposes in electronic or print form. You must obtain permission for any other use. Electronic or print copies may not be offered, whether for sale or otherwise to anyone who is not an authorised user. 


\section{Integration policies and adult second language learning in Finland}

\section{Sari Pöyhönen \& Mirja Tarnanen University of Jyväskylä, Finland}

Recent global changes (migration, transnationalism) have led to increasing diversification in Finland as well, even though the number of migrants is small compared to many other European countries. Inward migration to Finland has been concentrated in the larger centres in the Helsinki metropolitan area and Southern Finland. According to Statistics Finland, in March 2014, the number of the speakers of 'foreign languages' (293 540, or $5.4 \%$ ) exceeded for the first time in the country's history the number of the Swedish speakers $(290760$, or $5.3 \%$ ) of the population (5.4 million), permanently living in Finland. The largest language groups were Russian, Estonian, English, Somali and Arabic.

Following Johnson's (2009) lines of thinking and his useful distinction between three broad aspects of policy processes policy creation, interpretation and appropriation (in local practice), in this chapter, we provide a brief overview of integration policies and adult second language learning in Finland. This chapter also serves as an introduction to another chapter in this volume which showcases provision that has been developed in an inclusive way: stay-at-home mothers who have, hitherto, been labelled as being "problematic" and "challenging" in terms of social inclusion, employment, and education (see Intke-Hernandez, this volume).

In writing this chapter, we attempt to 'get behind' official policy interpretations by drawing on insights from two very different projects that we were involved from 2010 to 2014. The first project was a politically high-profile educational project, Participative integration into Finland, which was funded by several bodies, including government ministries responsible for integration policies, and cultural foundations. The terms of reference for the project were actually embedded in the Integration Act (2010). The overall aim was to enhance the prerequisites for the integration of immigrants. It involved facilitating and documenting local initiatives that were developing alternative forms of educational provision for different immigrant groups. These included groups with three different integration paths: adult immigrants seeking employment, adult immigrants needing special support (e.g. stay-at-home mothers, Intke-Hernandez, this volume), and children and adolescents. (The project outcomes were reported in Finnish and Swedish in an edited volume: Tarnanen et al. 2013). It also involved collaboration with local 
practitioners in developing the actual educational contents and initial stage guidance and counselling for migrant groups.

Our role in this project was that of external experts or policy advisors, since our research centre (Centre for Applied Language Studies) was commissioned to write the project's development plan. During the preparation of the plan, we interviewed various stakeholders in order to capture the range of views and get a full picture of the current policies and practices concerning integration and language education for adult immigrants. We conducted 30 individual and focus group interviews with civil servants based in the relevant Ministries, with staff from regional authorities and with local practitioners (social workers, counsellors in employment offices, and teachers) who were working directly with different migrant groups. All the stakeholders interviewed had Finnish as their first language, which illustrates the current stratification patterns in Finnish society. It is highly unusual for a person with a migrant background, who has Finnish as a second language, to be working in the public sector, especially in national and regional level institutions.

Once we had prepared a development plan, we were recruited as scientific mentors for the subprojects, and we visited local initiatives being carried out in 17 municipalities. During the project, we had direct experience of the policy process, from policy creation to its interpretation and local appropriation.

The second project we are drawing on here is an ongoing research project, Transforming

Professional Integration, which has been funded by the Academy of Finland for the years 2011-2014. The project aims to critically re-assess the roles and interplay of language proficiency, multilingual and multicultural practices and identities in working age migrants' integration to Finnish work and professional communities. In addition, we explore the significance of education paths regarding employment and connections between education and working life. In the project, the research team has conducted 60 interviews with migrants who are either working or seeking a job in Finland.

Our chapter has two broad sections: firstly, we present our historical account of the significant discursive shifts relating to migration that have taken place in government policy and in the media since the 1970s. Secondly, we take a close and critical look at current policy discourses and practices, describing the broad pathway that has been defined for migrants from right of 
residence to 'integration', taking account of the views expressed by different stakeholders and then identifying some of the issues arising at the level of practice, as the national policy and the curriculum for Finnish as a second language for adults has been appropriated - and contested locally. We conclude with a look at the future directions in integration policies and adult second language learning. We call for research of the type that can unpack the complexity of these issues related to policy appropriation in different local sites.

\section{Finnish legislation and government policy on integration: policy processes and discursive shifts over five decades (1970s-2010s)}

During the 1970s and 1980s, Finland was still largely country of outward emigration. Immigration was fairly sporadic and based on governmental responses to international humanitarian crises which led to the arrival and settlement of refugees. This first policy phase can be described as "fulfilling humanitarian obligations" (Saarinen 2011, 147). Finland joined the other Nordic countries in receiving refugees, mainly from Chile and Vietnam, through the auspices of the UN Commission for Human Rights.

During the second policy phase, in the 1990s, a discourse of a "national-ethnic obligation" predominated (Saarinen 2011, 148). Immigration mainly consisted of Ingrian Finns, who were repatriated after the collapse of the Soviet Union, and who were granted permanent residence. Ingrian Finns are descendants of Finns who moved, in the seventeenth century, to Ingria (St. Petersburg and Leningrad Region), when Finland was still part of the Kingdom of Sweden. In addition to the arrival of the Ingrian Finns, this phase also saw the arrival of significant numbers of refugees from Africa (e.g. Somalia), South-Eastern Europe (e.g. Former Yugoslavia), the Middle East (e.g. Iraq), and parts of Asia (e.g. Afganistan).

Finland joined the European Union (EU) in 1995. This started a new policy phase, namely that of "managed immigration" (Saarinen 2011, 148). Several measures were taken to control migration in accordance with the aims of the Dublin Convention and the Schengen Agreement. By the end of 1990s, Finnish integration policies were aimed at promoting freedom of movement within the terms of the EU legal framework. Finland was one of the first countries in the EU to pass an Integration Act in 1999. The Act emphasized residence-based social security, and did not pay so much attention to work-related inward migration. 
In the first decade of the twenty first century, there was an increase in work-related migration from the Eastern European nation states newly incorporated into the EU (e.g. from Estonia and Poland), along with work-related migration from outside the EU (e.g. South Asia, especially India), though there was a slight decline during the years of the economic recession. Migrant workers from Eastern Europe were recruited mostly into the construction industry and the service sector, while migration from South Asia was mostly related to the growth of the IT industry. This fourth policy phase has been described as one in which the key discourse was “immigration as a resource" (Saarinen 2011, 149). In 2003, the Government adopted an "active immigration policy" in its Programme for the years 2003-2007. The Central Party was the leading party at the time and formed the core of the government with the Social Democrats. In practice this meant promoting work-related migration and integration into working life in general, as well as intensified language teaching for adult immigrants. The aim was justified by the demographic trend towards an ageing population and the decline in the size of the workforce, especially in the service sector and in health care. The next Government (2007-2011) had similar aims, even though the combination of the political parties in power had changed (the Central Party was still in the leading position, but the National Coalition Party had replaced the Social Democrats).

Views changed quite dramatically after the Government Programme had been published. Economic recession was around the corner, unemployment rates were growing, and major initiatives to promote work-related migration did not receive political support. Thus, the "active immigration policy" soon vanished from the policy agenda. Yet, the aim of intensifying and increasing provision of language courses for adult migrants remained unchanged.

The fifth policy phase has been called one of "contested immigration" (Saarinen 2011, 150). Over the past decade, Finland has changed from being a country of net emigration into a country of net inward migration. It has been estimated that by the end of 2030 there will be around 500000 "foreign citizens" in Finland (The Ministry of Employment and Economy 2012). Critical voices opposed to migration, integration, and multiculturalism have become louder, and the discussion has been heavily problem-oriented.

Critical comments have also been voiced by those who are in favour of integration and multiculturalism. Some have argued that insufficient attention has been given in national debates to migrants' own points of view (e.g. Saarinen 2011). Others have shown concern about the cultural, historical and political differences between migrant groups being erased (e.g. Saukkonen 
2013). Yet others have pointed out that no account is taken of the differences, in experience, cultural orientations and communicative repertoires, across the generations, among groups of migrant origin (e.g. Rynkänen \& Pöyhönen 2010). Different stakeholders (policy makers, civil servants, teachers, migrants, employers) have different views on the aims and means of appropriation of policies of migration and integration. As we have tracked the discourses on migration and integration over the last five years or so, it has become clear that they are in a state of flux and are sometimes contradictory (Holm \& Pöyhönen 2012).

At a time of growing criticism, the Promotion of Immigrant Integration Act was introduced in the end of the year 2010, a few months before the Parliamentary elections, and it came into full force in autumn 2011. The Act was meant to take a more holistic view of integration, paying attention to the diversity of migrant groups. In the first sentence of the Act, its purpose is stated "to support and promote integration and make it easier for immigrants to play an active role in Finnish society" (Integration Act 2010, Chapter 1, Section 1). Official Finnish policy is discursively constructed as tolerant and promoting integration rather than assimilation. The Act (2010, section 3) defines integration as "interactive development involving immigrants and society at large, the aim of which is to provide immigrants with the knowledge and skills required in society and working life, and to provide them with support, so that they can maintain their culture and language." The legislation emphasizes the need for multi-sectoral cooperation, that is between local authorities (e.g. municipalities, job offices, police) and other parties, such as nongovernmental organisations, in order to promote integration.

Even though the aims of this version of Finnish integration policy seemed positive on the surface, it generated a good deal of criticism in various arenas, including political parties and trade unions, local authorities, educational institutions, academia, the press and internet discussion forums. The Parliamentary elections in April 2011 proved to be a wake-up call for those Finns who were promoting integration and multiculturalism. The populist nationalist party, the Finns Party (previously known as the True Finns), received $19.1 \%$ of the vote and gained 39 seats out of 200. Previously, they had held five. The main political agenda of the Finns Party, since its foundation, has been criticism of migration policies, and although its supporters are not uniform in their views, some of its members express outright racist or xenophobic opinions in public. Moreover, the Finns Party now collaborates with right-wing nationalist parties of the EU member states in the European Parliament. After the elections, the party opted out of the negotiations around the formation of a coalition government. 
The programme of the 2011-2014 government was formed as a result of a pact between the National Coalition Party, the Social Democrats and four other political parties. The government explicitly espouses a discourse of pluralism. It responds to the Finns Party and to other antiimmigration forces with the message that "immigrants are a permanent and welcome part of Finnish society" (Government Programme 2011, 45). This particular discourse was foregrounded in the 2010 legislation. Yet, in practice, priority has been given to those groups of immigrants who, in the government's view, are able to play a role in enhancing Finland's international competitiveness. The government programme could be said to have incorporated a mixture of left and right wing politics and different discourses: a cocktail of humanitarian aims and discourses and a neo-liberal stance on the economy and the labour market, which is manifested in a preoccupation with 'skills'.

\section{Finnish as a second language for adults: official curriculum and pedagogy and stakeholders' views}

Integration training in Finland is based on two pieces of legislation: the Act on the Promotion of Integration (1386/2010) and the Act on Public Employment Service (1198/2009). As the integration training is primarily defined as labour market training, adult migrants, students, are 'clients' of the job office. The aim of the training is to promote vocational competencies; although general education may be acknowledged as part of integration training if it supports further career plans and employment (FNBE 2012a).

From our analysis of the interviews that we conducted with Finnish stakeholders it is clear that stakeholders at all levels (national-regional-local) supported the official integration policy, its strategic discourse and the plans for implementation. Most of the stakeholders regarded entry into the labour market as the primary goal of integration for adult migrants, as the following quotations suggest:

"We start from the assumption that the labour market is what we are aiming for". (Ministry of Interior)

"We sort of train these people for working life right from the beginning". (Finnish language teacher) 
The National Core Curriculum for integration training for adult migrants $(2012,11)$ echoes the ethos of the Integration Act by stating that integration training "aims to support migrants" integration by developing those linguistic, civic, cultural and life skills that help migrants to cope with everyday life situations in their new environment and be capable of functioning in working life and of applying for further studies." The curriculum has a legal status, whereas the four previous ones (1993, 1997, 2001 and 2007) were recommendations and were not binding for educational institutions. This shift in the status of the curriculum from a recommendation to a statutory requirement can be interpreted in two ways. On the one hand, it can be considered as an attempt to raise the status of integration training in the field of education and the labour market and, on the other hand, as in other countries of the EU, it can be seen as a mean of furthering integration in the spirit of the current integration policy which emphasizes the importance of learning the target language as a means of access to welfare, participation, and employment (cf. Nohl, Schittenhelm, Schmidtke \& Weiss 2006; Pujolar 2010).

The scope and content of integration training are supposed to vary according to each student's individual needs and with reference to the baseline level for assessment. Integration training includes Finnish/Swedish language and communication skills and civic and working life skills. It also includes guidance counselling and one or more work placement periods. The objective of integration training is for a student to achieve skill level B1.1 in the Finnish or Swedish language although the skill level to be achieved during the training may vary depending on the student's employment opportunities, educational background, and further career plans (FNBE 2012a). For the migrants who have relatively little previous experience with reading and writing in languages other than Finnish or Swedish there is a separate curriculum. (FNBE 2012b.) Even though the curriculum is called the "National Core Curriculum for Literacy Training" and is informed by the same broadly positive discourse about integration and diversity, the discourse about literacy and the interpretations of the curriculum appear to be cast in largely deficit terms. This is particularly evident in the categorizations of students as: "people with primary illiteracy", "people with secondary illiteracy" and "semi-literate people". This terminology is reminiscent of deficit discourses about language and literacy that have been widely critiqued in other European settings by a number of researchers (cf. Martin-Jones and Romaine 1986; Stroud 2004; Holm and Laursen 2011). 
Most of the interviewees participating in our educational project agreed with the overall idea of perceiving adult learners as active participants in the learning process. However, problemoriented discourses also surfaced, and the stakeholders brought various images of migrants to the fore. Sometimes, individual interviewees articulated contradictory positions on particular topics within the same interview. A quite common discursive strategy was to represent migrants as distinct groups defined on the basis of their reason for their move to Finland (asylum seekers and refugees vs. work-based migrants). Another common discursive trope was that of categorizing migrants on the basis of their language and literacy skills (those with little or no reading and writing skills vs. those with a schooled background).

In addition to the characterization of groups as distinct, certain groups were seen as being at risk in terms of integration. These groups were adolescent drop-outs, stay-at-home mothers, the elderly, and certain ethnic groups, such as the Russians and the Somalis. A recurring theme in the interviews was that these groups faced 'obstacles in integration'. These obstacles were linked to age, social class, or ethnicity. Some interviewees, in particular those of migrant origin, raised critical questions regarding this discourse about 'obstacles in integration'. Take, for example, this quotation from one of our interviews:

\footnotetext{
"If you're willing to integrate yourself it is easier, though I must remind [you] that it's never really up to the person who tries to integrate. Integration happens through the society. You can try as much as you want to be accepted ... if the society doesn't accept you can do whatever you want. You can speak Finnish fluently, you can have a job, whatever, but if people for example don't like you, because of your colour or something there's nothing you can do about it."
}

\section{Finnish as a second language for adults: issues arising from current practice}

In practice then, integration training consists of Finnish (or Swedish) language classes and work life and civic skills classes, and a work placement period. Classes are arranged during working hours, and the length of training is about 25 hours per week. The participants are usually placed in groups after they have been assessed through the use of a language proficiency scale. There is also an assessment of learning skills in general. The explicit aim of this assessment is to better support individual learning paths and aims. In the interviews we carried out with various stakeholders, this assessment procedure was mostly seen as welcome, particularly by teachers, 
but it was also criticized for being a political tool that served as a means of creating new categories for social selection (Holm and Pöyhönen 2012).

From the work that we have done on both projects, we have been able to ascertain that the teachers are mainly people who have been trained as Finnish L1 language teachers and who mostly have an MA degree. Civic and working life skills are taught by teachers with various disciplinary backgrounds, such as social studies and anthropology. Even though the teachers are highly educated they have rather weak ties to working life, and thus little direct experience of the kinds of language and literacy resources that are actually needed to be able to cope with various job tasks and/or they have had little experience of using authentic material from working life in their teaching (cf. Roberts and Cooke 2009; Lindberg and Sandwall 2012).

Even though the pedagogic principles of the curriculum seem progressive (e.g. the socioconstructivist approach), they are not necessarily implemented in integration training itself. Classroom instruction has been criticized for being teacher-oriented, grammar-based, and text book and handout driven. In addition, the view of adult second language learning underpinning the Curriculum and pedagogical practice has been strongly criticized for not taking into account, among other things, the complex, changing, and dynamic nature of literacies in contemporary life and their role in identity construction. (Holm and Pöyhönen 2012.)

Moreover, the physical layout of classrooms, such as those we have observed in our research, and the asymmetric relation of power between teacher and students inevitably shape the lived experiences of teaching and learning and contribute to the reproduction of dominant discourses about what counts as legitimate knowledge and skills and what counts as being a student in integration training courses. Indeed, one could ask what institutional worlds and pedagogic discourses (Bernstein, 1996) the students are being socialized into (see also Baynham \& Simpson 2010).

On the whole, progressive proposals for educational policy development, including curriculum development, are based on visions of education which prioritize equalizing educational opportunities for all students and which value diversity, action-oriented learning, and individual education paths. It now seems to be generally accepted that the success of such policies depends on the micro-level practices of local educators (Hornberger and Johnson, 2007; Egbo 2005; Ramanathan 2002). As we have shown in this chapter, there are ongoing debates in Finland 
about the question of whether integration training supports the activity, participation and autonomy of students or - quite the opposite - whether it socializes them into becoming regular 'clients' of social services waiting for access to the labour market (see also Intke-Hernandez, this volume). The value of integration training has already been questioned in public forums, although a number of development projects and official bulletins seem to argue for the continued need of integration training in order to achieve full participation in society, including employment. However, there are no statistics available for the employment status of the persons who have gone through integration training. From what we have seen in this field over the last five years, it is likely that the training paths lead either to precarious jobs or to business start-ups rather than to the regular employment contracts anticipated in the training received.

Among policy-makers and integration educators in Finland, there is still a firm belief that language proficiency and literacy skills have the power to change the material circumstances of migrants who are marginalized until they reach the targets defined for integration training and fulfil the aims of integration policy (similar discourses circulate in other national contexts e.g., Blackledge 2006). Yet, there is a mismatch between the content and pedagogical practices of integration training and migrants' needs, whether they are heading for the labour market or trying to find their place in society in other ways. Even though the curriculum is fairly flexible, the practices seem to favour a one-size-fits-all type of approach, e.g., teacher-led classroom practices and paper and pencil oriented materials. Integration training is not just about learning the language and civic and work skills, but also about a complex process of identification interfacing with classroom practices that position adult participants as 'students' and limit their agency, making it difficult for them to forge new identities in their new country using the communication resources available to them (cf. Norton 2010).

\section{Future directions}

The creation, interpretation and appropriation of integration policies, including adult second language teaching and learning, are complex processes that involve different participants on different scales. As we have shown, there has been a series of changes on a national scale in Finland in both policy and practices. These changes have taken the form of, for example legislation; changes in the stances of the political parties; reorganization of the integration administration; curricula and various projects for developing integration training, for introducing measures and co-operation between administrative bodies, for providing guidance, and for 
promoting employment opportunities. It is still too early to assess the impacts of these policy changes, but the changes themselves appear to be the main governmental response to the increasing flow of migrants to Finland and to the growing public debates about inward migration. They also reflect the official migration policy of the European Union, and the principle of 'two-way integration', which is often represented as a process of mutual accommodation between migrants and the receiving societies. These changes have also been accompanied by a changing discourse about setting threshold levels for language proficiency, giving rise to discussions about the profiling of migrants, and the possible introduction of new testing regimes for citizenship. These new set of discourses resonate with discourses circulating in other national contexts (cf. Blackledge 2006; Extra, Spotti \& van Avermaet 2009).

There is still no shared political agreement on who will oversee the integration of adult migrants who are temporarily or permanently outside working life, e.g. stay-at-home mothers or adults who have relatively little experience of reading and writing in languages other than Finnish or Swedish. The main responsibility for dealing with the needs of these groups is shouldered by the municipalities, but they are facing difficulties in providing services for all, mainly due to lack of financial resources, but also due lack of experience. National policies and local realities do not meet each other in this area of provision.

Moreover, there seems to be no end to polarized discussion concerning the future of inward migration and integration policies. Consequently, there will be more debate among politicians, citizens and local authorities as to whether to favour highly skilled migrants instead of unskilled migrants. The voice of migrants themselves will continue to be largely overlooked. Immigration policy and questions of integration cover multiple domains and research fields. There are still major gaps in our understanding of how processes of policy creation, interpretation and appropriation actually work and how the learning experiences and economic circumstances of individual migrants can be improved. To deepen our understanding and to build a comprehensive picture of the policy processes currently at work in Finland, and other countries in Europe, comparative interdisciplinary research of a critical, ethnographic nature will be needed.

\section{References}

Baynham, M. and J. Simpson (2010) 'Onwards and Upwards: Space, Placement and Liminality in Adult ESOL Classes.' TESOL Quarterly 44/3, 420-440. 
Bernstein, B. B. 1996. Pedagogy, symbolic control, and identity: Theory, research, critique. London: Taylor $\&$ Francis.

Blackledge, A. 2006. "The men say 'They don't' need it"' Gender and extension of language testing for British citizenship. Studies in Language \& Capitalism 1, 143-161.

Egbo, B. 2005. Critical pedagogy as transformative micro-level praxis. AE-Extra, accessed 28 May 2013 on http://www.unco.edu/ae-extra/2005/6/Art-4.html .

Extra, G., Spotti, M. \& van Avermaet, P. 2009. Language testing, migration and citizenship: Crossnational perspectives on integration regimes. London and New York: Continuum.

Finnish National Board of Education 2012a. National Core Curriculum for Integration Training for Adult Migrants 2012. Helsinki: Finnish National Board of Education.

Finnish National Board of Education 2012b. National Core Curriculum for Literacy Training for Adult Migrants 2012. Helsinki: Finnish National Board of Education.

Government Programme 2011. Programme of Prime Minister Jyrki Katainen’s Government. Prime Minister's Office. Finland.

Holm, L. \& Laursen H.P. 2011. Migrants and Literacy Crises. Apples - Journal of Applied Language Studies 5 (2), 3-16.

Holm, L. \& Pöyhönen, S. 2012. Localising supranational concepts of literacy in adult second language teaching. In A. Pitkänen-Huhta \& L. Holm (eds.) Literacy practices in transition: Perspectives from the Nordic countries. Bristol: Multilingual Matters, 191-210.

Hornberger, N. \& Johnson, D. C. 2007. Slicing the onion ethnographically: Layers and spaces in multilingual language education policy and practice. TESOL Quarterly 41 (3), 509-532.

Integration Act 2010. Act on the Promotion of Immigrant Integration (1386/2010). Ministry of the Interior. Finland. Unofficial translation.

Johnson, D. C. 2009. Ethnography of language policy. Language Policy 8, 149-159.

Lindberg, I. \& Sandwall, K. 2012. Samhälls- och undervisningsperspektiv på svenska som andraspråk för vuxna invandrare. In K. Hyltenstam, M. Axelsson \& I. I.indberg (eds.) Vetenskapsrådet: Flerspråkighet - en forskningsöversikt. Göteborg: University of Gothenburg, 368-502.

Martin-Jones, M. and Romaine, S. 1986. 'Semilingualism': a half-baked theory of communicative competence. Applied Linguistics, Vol. 7, No. 1, 26-38.

Nohl, A-M, Schittenhelm, K., Schmidtke, O. \& Weiss, A. 2006. Cultural Capital during Migration-A Multi-level Approach to the Empirical Analysis of Labor Market Integration amongst Highly Skilled Migrants. Qualitative Migration Research in Contemporary Europe, 7, 3,

Norton, B. 2010. Language and identity. In Hornberger, N. H. \& McKay, L. S. (eds.) Sociolinguistics and Language Education. Bristol: Multilingual Matters, 369-370.

Pujolar, J. 2010. Immigration and language education in Catalonia: Between national and social agendas. Linguistics and Education 21, 229-243.

Ramanathan, V. (2002). The Politics of Tesol Education: Writing, Knowledge, Critical Pedagogy. New York: Routledge.

Roberts, C. \& Cooke, M. 2009. Authenticity in the Adult ESOL Classroom and Beyond. Tesol Quarterly 43,4, 620-641.

Rynkänen, T. \& Pöyhönen, S. 2010. Russian-speaking young immigrants in Finland: Educational and linguistic challenges to integration. In M. Lähteenmäki \& M. Vanhala-Aniszewski (eds.) Multilingualism in Finland and Russia. Language Ideologies in Transition. Frankfurt am Main: Peter Lang, 175-194.

Saarinen, A. 2011. Non-work migration, employment and welfare in Finland: Three ten cases and four phases of immigration policies. In Mojca Pajnik \& Giovanna Campani (eds.) Precarious migrant labour across Europe. Ljubljana: Mirovni institut, 145-170. 
Saukkonen, P. 2013. Multiculturalism and Natonalism: The Politics of Diversity in Finland. In Ö. Wahlbeck and P. Kivisto (eds.) Debating Multiculturalism in the Nordic welfare states. Basingstoke: Palgrave Macmillan, 270-294.

Stroud, C. 2004. Rinkeby Swedish and semilingualism in language ideological debates: A Bourdieuean perspective. Journal of Sociolinguistics 8 (2), 196-214.

Tarnanen, M., Pöyhönen, S., Lappalainen, M. \& Haavisto, S. (eds.) 2013. Osallisena Suomessa kokeiluhankkeiden satoa. Delaktig i Finland - skörden från försöksprojekten. Participative Integration into Finland - harvest from the pilot projects]. Jyväskylä and Helsinki: University of Jyväskylä, Finnish Cultural Foundation \& Swedish Cultural Foundation. 